\title{
Front Matter: Volume 8996
}

, "Front Matter: Volume 8996," Proc. SPIE 8996, Quantum Dots and Nanostructures: Synthesis, Characterization, and Modeling XI, 899601 (17 March 2014); doi: 10.1117/12.2063498

SPIE. Event: SPIE OPTO, 2014, San Francisco, California, United States 


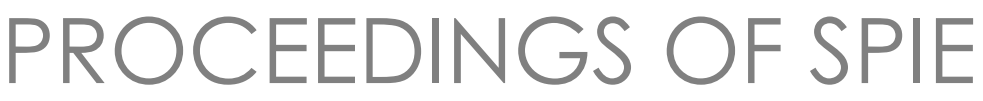

\title{
Quantum Dots and Nanostructures: Synthesis, Characterization, and Modeling XI
}

\author{
Diana L. Huffaker \\ Frank Szmulowicz \\ Holger Eisele \\ Editors
}

3-5 February 2014

San Francisco, California, United States

Sponsored and Published by

SPIE 
The papers included in this volume were part of the technical conference cited on the cover and title page. Papers were selected and subject to review by the editors and conference program committee. Some conference presentations may not be available for publication. The papers published in these proceedings reflect the work and thoughts of the authors and are published herein as submitted. The publisher is not responsible for the validity of the information or for any outcomes resulting from reliance thereon.

Please use the following format to cite material from this book:

Author(s), "Title of Paper," in Quantum Dots and Nanostructures: Synthesis, Characterization, and Modeling XI, edited by Diana L. Huffaker, Frank Szmulowicz, Holger Eisele, Proceedings of SPIE Vol. 8996 (SPIE, Bellingham, WA, 2014) Article CID Number.

ISSN: 0277-786X

ISBN: 9780819499097

\section{Published by}

\section{SPIE}

P.O. Box 10, Bellingham, Washington 98227-0010 USA

Telephone +1 3606763290 (Pacific Time) · Fax +1 3606471445

SPIE.org

Copyright @ 2014, Society of Photo-Optical Instrumentation Engineers.

Copying of material in this book for internal or personal use, or for the internal or personal use of specific clients, beyond the fair use provisions granted by the U.S. Copyright Law is authorized by SPIE subject to payment of copying fees. The Transactional Reporting Service base fee for this volume is $\$ 18.00$ per article (or portion thereof), which should be paid directly to the Copyright Clearance Center (CCC), 222 Rosewood Drive, Danvers, MA 01923. Payment may also be made electronically through CCC Online at copyright.com. Other copying for republication, resale, advertising or promotion, or any form of systematic or multiple reproduction of any material in this book is prohibited except with permission in writing from the publisher. The CCC fee code is 0277-786X/14/\$18.00.

Printed in the United States of America.

Publication of record for individual papers is online in the SPIE Digital Library.

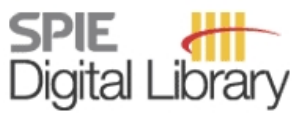

SPIEDigitalLibrary.org

Paper Numbering: Proceedings of SPIE follow an e-First publication model, with papers published first online and then in print and on CD-ROM. Papers are published as they are submitted and meet publication criteria. A unique, consistent, permanent citation identifier (CID) number is assigned to each article at the time of the first publication. Utilization of CIDs allows articles to be fully citable as soon as they are published online, and connects the same identifier to all online, print, and electronic versions of the publication. SPIE uses a six-digit CID article numbering system in which:

- The first four digits correspond to the SPIE volume number.

- The last two digits indicate publication order within the volume using a Base 36 numbering

system employing both numerals and letters. These two-number sets start with 00, 01, 02, 03, 04, 05, 06, 07, 08, 09, 0A, 0B ... 0Z, followed by 10-1Z, 20-2Z, etc.

The CID Number appears on each page of the manuscript. The complete citation is used on the first page, and an abbreviated version on subsequent pages. Numbers in the index correspond to the last two digits of the six-digit CID Number. 


\section{Contents}

$\checkmark \quad$ Conference Committee

INTEGRATED NANOSTRUCTURES

899602 Molecular beam epitaxial growth and characterization of intrinsic and p-type InN nanowires (Invited Paper) [8996-1]

Z. Mi, S. Zhao, B. H. Le, McGill Univ. (Canada); O. Salehzadeh, S. Alagha, K. L. Kavanagh,

S. P. Watkins, Simon Fraser Univ. (Canada)

$899606 \quad$ Epitaxial growth of quantum dots on InP for device applications operating at the $1.55 \mu \mathrm{m}$ wavelength range [8996-5]

E. S. Semenova, I. V. Kulkova, S. Kadkhodazadeh, Technical Univ. of Denmark (Denmark);

D. Barettin, Univ. of Rome Tor Vergata (Italy); O. Kopylov, A. Cagliani, K. Almdal,

M. Willatzen, K. Yvind, Technical Univ. of Denmark (Denmark)

\section{NANOWIRE EPITAXY AND THEORY}

$899608 \quad$ Nonplanar nanoselective area growth of InGaAs/InP [8996-7]

N. Kuznetsova, P. Colman, E. Semenova, S. Kadkhodazadeh, Technical Univ. of Denmark (Denmark); N. V. Kryzhanovskaya, St. Petersburg Academic Univ. (Russian Federation);

S. Ek, W. Xue, Technical Univ. of Denmark (Denmark); M. Schubert, Technical Univ. of Denmark (Denmark) and The Univ. of Konstanz (Germany); A. E. Zhukov, St. Petersburg Academic Univ. (Russian Federation); K. Yvind, Technical Univ. of Denmark (Denmark)

\section{NANOSTRUCTURE CHARACTERIZATION}

8996 OE Electrical characterization of semiconductor nanowires by scanning tunneling microscopy (Invited Paper) [8996-11]

C. Durand, Institut d'Electronique de Microélectronique et de Nanotechnologie, CNRS (France) and Oak Ridge National Lab. (United States); P. Capoid, M. Berthe, Institut d'Electronique de Microélectronique et de Nanotechnologie, CNRS (France); T. Xu, Institut d'Electronique de Microélectronique et de Nanotechnologie, CNRS (France) and Shanghai Univ. (China); J.-P. Nys, R. Leturcq, Institut d'Electronique de Microélectronique et de Nanotechnologie, CNRS (France); Ph. Caroff, Institut d'Electronique, de Microélectronique et de Nanotechnologie, CNRS (France) and The Australian National Univ. (Australia); B. Grandidier, Institut d'Electronique, de Microélectronique et de Nanotechnologie, CNRS (France)

8996 OG Optical and electrical characterization of surface passivated GaAs nanostructures [8996-13]

S. Arab, C. Y. Chi, M. Yao, C.-C. Chang, P. D. Dapkus, S. B. Cronin, The Univ. of Southern California, Los Angeles (United States) 
8996 OM Plasmon-enhanced ultrathin bulk heterojunction: interplay between optical and thermal responses of AuNPs [8996-41]

S. Shahin, P. Gangopadhyay, R. A. Norwood, College of Optical Sciences, The Univ. of Arizona (United States)

\section{QUANTUM DOT DEVICES}

8996 OP Investigation of quantum efficiency in mid-wave infrared (MWIR) InAs/GaSb type-II strained layer superlattice (T2SL) detectors [8996-21]

L. Acosta, B. Klein, Z.-B. Tian, Ctr. for High Technology Materials, The Univ. of New Mexico (United States); E. Frantz, Univ. of Cincinnati (United States); S. Myers, SKINfrared LLC (United States); N. Gautam, Univ. of California, Santa Barbara (United States); T. Schuler-Sandy, E. Plis, S. Krishna, Ctr. for High Technology Materials, The Univ. of New Mexico (United States)

POSTER SESSION

8996 OY Structural and optical characterization of fresh water diatoms (Cyclotella sp.): nature's nanoporous silica manufacturing plant [8996-30]

N. Mazumder, National Yang-Ming Univ. (Taiwan); A. Gogoi, Jagannath Barooah College (India); A. K. Buragohain, G. A. Ahmed, A. Choudhury, Tezpur Univ. (India)

899612 Substrate-induced effects on the plasmonic properties of strongly coupled silver nanocubes [8996-34]

D. Prezgot, A. Ianoul, Carleton Univ. (Canada)

899613 Plasmonic properties of silver nanocube monolayers deposited on thin metal films [8996-35]

A. Bottomley, A. Ianoul, Carleton Univ. (Canada)

899615 Optimisation study of the synthesis of vanadium oxide nanostructures using pulsed laser deposition [8996-39]

B. N. Masina, CSIR National Laser Ctr. (South Africa) and Univ. of KwaZulu-Natal (South Africa); S. Lafane, Ctr. de Développement des Téchnologies Avancées (Algeria); L. Wu, Univ.of KwaZulu-Natal (South Africa); S. Abdelli-Messaci, T. Kerdja, Ctr. de Développement des Téchnologies Avancées (Algeria); A. Forbes, CSIR National Laser Ctr. (South Africa) and Univ. of KwaZulu-Natal (South Africa)

Author Index 


\section{Conference Committee}

Symposium Chairs

David L. Andrews, University of East Anglia Norwich (United Kingdom)

Alexei L. Glebov, OptiGrate Corporation (United States)

Symposium Co-chairs

Jean Emmanuel Broquin, IMEP-LAHC (France)

Shibin Jiang, AdValue Photonics, Inc. (United States)

Program Track Chair

Ali Adibi, Georgia Institute of Technology (United States)

Conference Chairs

Diana L. Huffaker, University of California, Los Angeles (United States) Frank Szmulowicz, University of Dayton Research Institute (United States)

Holger Eisele, Technische Universität Berlin (Germany)

Conference Program Committee

Alberto Bramati, Université Pierre et Marie Curie (France)

Massimo De Vittorio, Università del Salento (Italy)

Axel Hoffmann, Technische Universität Berlin (Germany)

Minjoo L. Lee, Yale University (United States)

Hui-Yun Liu, University College London (United Kingdom)

Vinod M. Menon, Queen's College (United States)

Zetian Mi, McGill University (Canada)

Jeffrey C. Owrutsky, U.S. Naval Research Laboratory (United States)

Gregory J. Salamo, University of Arkansas (United States)

Jonathan Spanier, Drexel University (United States)

Session Chairs

1 Integrated Nanostructures

Holger Eisele, Technische Universität Berlin (Germany)

2 Nanowire Epitaxy and Theory

Adam Scofield, University of California, Los Angeles (United States) 
3 Nanowire Devices

Zetian Mi, McGill University (Canada)

4 Nanostructure Characterization

Adam Scofield, University of California, Los Angeles (United States)

5 Quantum Dot Emission

Frank Szmulowicz, University of Dayton Research Institute (United States)

6 Quantum Dot Devices

Enrique Calleja, Universidad Politécnica de Madrid (Spain)

7 Nanomaterials

Frank Szmulowicz, University of Dayton Research Institute (United States) 